\title{
Soil geochemistry of the municipality necropolis of Mata, RS, by fluorescence of $x$-rays by dispersive energy
}

\author{
Cristiane Heredia Gomes '; Diogo Gabriel Sperandio " \\ Guilherme Pazinato Dias "'" ; Arthur Pedroso Viçozzi IV
}

\begin{abstract}
The Corda river is the main source of fresh water for recreation, leisure, supply and irrigation to the municipality of Barra do Corda - MA. The objective of the present study was to evaluate the physicochemical parameters of Corda river's water using the methodology described by the American Public Health Association. The water samples were collected in the seasonal period spanning between February and September of the year of 2018. The parameters which were analyzed during the study were $\mathrm{pH}$, conductivity, turbidity, total dissolved solids and salinity, besides concentrations of nitrite, nitrate, and total phosphorus. Three principal components were identified during the PC Analysis. Those components explain more than $74 \%$ of the total variance observed during the rainy and dry season. Axis 1 and 2 included variables which were related to quality of water and could be affected by the change in seasons. The results indicated that $\mathrm{pH}(7.11), \mathrm{P}\left(2.82 \mathrm{mg} \mathrm{L}^{-1}\right), \mathrm{NO}_{3}^{-}\left(3.23 \mathrm{mg} \mathrm{L}^{-1}\right)$, turbidity (35.82 NTU) and conductivity $(35.83 \mu \mathrm{S} / \mathrm{cm})$ parameters were most affected by changing from rainy to dry season.
\end{abstract}

Keywords: Physicochemical parameters; Contamination; Water; Principal component analysis

\footnotetext{
' Federal University of Pampa, Caçapava do Sul, Brazil. cristianegomes@unipampa.edu.br

"Federal University of Pampa, Caçapava do Sul, Brazil. gabrielspe@gmail.com@gmail.com

III Federal University of Pampa, Caçapava do Sul, Brazil. gui.pazinato.dias@gmail.com

Iv Federal University of Pampa, Caçapava do Sul, Brazil. arthurvicozzi@gmail.com
} 


\section{INTRODUCTION}

Cemeteries generate environmental impacts and damage to public health (BRASIL, 2006) due to the fact that when the decomposition of the bodies occurs a necrochorume release to the environment in a proportion relative to the body mass of $0.6 \mathrm{~L} \mathrm{~kg}^{-1}$ (SILVA, 2000), basically a mixture of water, mineral salts and organic substances. Although in this mixture there may be large amounts of diseases associated with bacteria, viruses and protozoa, depending on the cause of death, there are also rich in sulfur gases, carbon, methane, ammonia and phosphorus and elements such as Ti, Cr, Cd, Pb, Fe, Mn, $\mathrm{Hg}$ and Ni (SPONGBERG; BECKS, 2000).

These chemical pollutants represent sources of soil contamination and, consequently, of nearby water resources, as they can accumulate in the soil and, also be transported to rivers, streams and creeks and then infiltrate the aquifers. Consequently, in these areas there is an increase in electrical conductivity, $\mathrm{pH}$, alkalinity and soil hardness (Matos, 2001), as well as an increase in the adsorption behavior of metals by the soil, generating unfavorable effects and high concentrations of harmful metals, like Zn, Cd, Cu e Pb (JORDÃO et al. 2000).

A combination of inorganic and organic substances constitutes the soil, being controlled by climatic and anthropic conditions. Inorganic substances of environmental interest are commonly called heavy metals. Some metals are designated as soil pollutants, but this expression applies to elements that have a specific weight bigger than $5 \mathrm{~g} . \mathrm{cm}^{-3}$ or to those elements which the atomic number is higher than 20 (MALAVOLTA, 1994). The soils, because they present such a wide variety of adsorption sites, can retain metals in iron oxides, aluminum and manganese, and in carbonates. In this case, the soil and horizon class significantly affect the adsorption and, consequently, the mobility of some metals such as $\mathrm{Zn}, \mathrm{Cd}$, and $\mathrm{Cu}$. The transport of the solute that does not interact with a porous medium, for example, characterizes an abrupt contamination and disperses with a velocity equal to the average linear of the percolating fluid (PINTO, 2000; REIMANN et al. 2008). Thus, 
if Darcy's law is considered, the hydraulic conductivity represents a resistance of the medium to the water percolation and its dissolved contaminants.

On the other hand, Gonçalves et al. (2008) suggests that more sandy soils, which have high percolation velocity, promote higher dispersion-diffusion coefficients than the clayey soils. The dispersion-diffusion coefficient can be indicative of the soil capacity in retaining a certain solute. In addition, the concentration of the contaminant, the density of the flow and the speed of the water influence the quantity transported. In any case, both physical and chemical processes influence the transport of soil contaminants. The control of contaminants becomes essential for the evaluation of the damage caused to the population.

Based on this, this study aims to analyze the geochemistry alterations of the municipality necropolis of Mata soil, in the Rio Grande do Sul state. In order to detect and evaluate metals in the investigated soils in a simple, fast and low-cost manner, the Energy Dispersive X-ray Fluorescence (EDXRF) was used to evaluate the changes in the content of the present chemical elements (WASTOWSKI et al. 2010). The Principal Component Analysis method is also used here to help identify the close relationship between sample and variables (LAWRENCE; UPCHURCH, 1982). Multivariate statistical analysis has been successfully applied, in which it has helped to simplify and organize a large number a large number of data and show the anthropic impact and/or investigate soil contamination (GOMES et al. 2018a; GOMES et al. 2018b).

\section{LOCATION AND DESCRIPTION OF THE AREA UNDER STUDY}

Mata is located in the northwest of the Rio Grande do Sul state, at latitude $29^{\circ} 33^{\prime} 57^{\prime \prime} \mathrm{S}$ and longitude $54^{\circ} 27^{\prime} 36^{\prime \prime} \mathrm{W}$, with an altitude of 127 meters above the average sea level, in an area of $311.883 \mathrm{~km} 2$ and with an estimate population of 4.864 (IBGE, 2018). 
Figure 1 - Location map of the research area in the city of Mata, RS

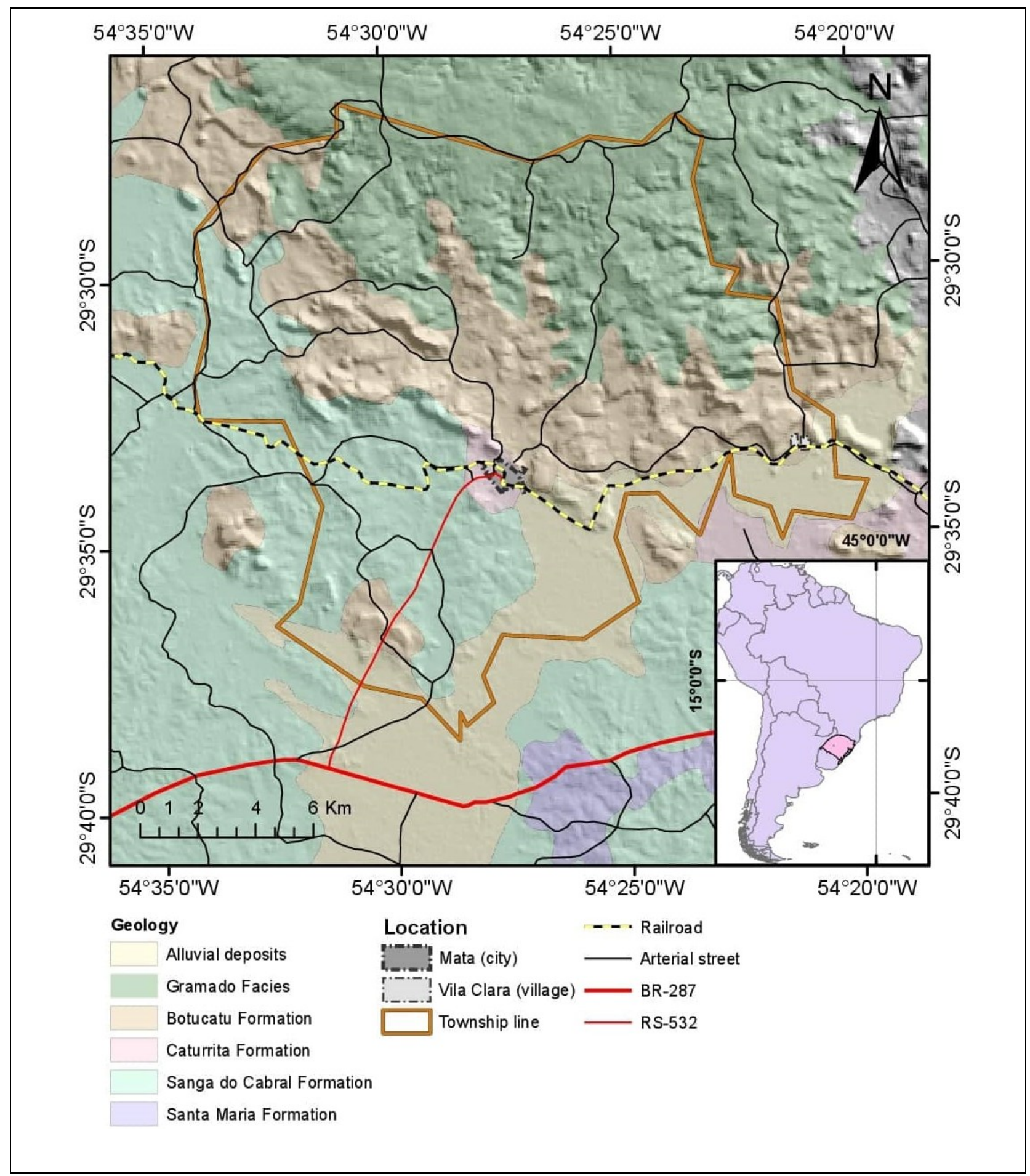

The study site is located on the Botucatu Formation, which belongs to the São Bento Group. This still encompasses the Pirambóia and Serra Geral Formations (Figure 1). According to Scherer et al. (2000), the upper limit of the Botucatu Formation corresponds to the Neocomian age, coinciding temporally with the first strokes of the Serra Geral Formation. However, its initial deposition age is not clearly defined, being 
understood between the Jurassic and the Inferior Cretaceous (SCHERER et al. 2000). The Botucatu Formation is characterized as a large desert, whose main sedimentary structures are the large cross stratifications having in the top flat-parallel and trough cross-bedding. This formation is divided into three faciological associations, the first consisting of coarse-grained sandstone, which occurs in the form of staple lenses with a maximum thickness of 1 meter; The second facies consists of sandstones with crossed strata, linked to the migration of growing dunes; And the third facies is also composed of sandstones with crossed strata, linked to the migration of complex linear dunes (PARAGUASSU, 1970). Portions close to the Serra Geral volcanism present areas of silicified sandstone (PARAGUASSU, 1970). In the study area, the Botucatu Formation consists of quartz and sandstone to subarcoseans of a reddish color and relatively homogeneous composition resulting from wind transport.

The municipal necropolis of Mata is located in the urban region of the city, where it occupies an area of 246 meters and is characterized by being a horizontal cemetery used for this purpose since the 17th century, consisting of graves constructed of bricks and cement that store drawers. It is estimated that there are about 100 bodies in these graves over 16 blocks, paved of not in the cemetery area (Figure 2). In the vicinity of the cemetery there is the occurrence of tobacco plantation (direction NE and SE), native forest and are with anthropic occupation (NW).

As for pedology in the study area, the soils are classified as podzolic, being characteristic of humid climate according to the Embrapa Classification (EMBRAPA, 1999). The coloration varies from dark red to yellow and greyish yellowish-red (STRECK et al. 2002; ABNT, 1995). The red and yellow color is related to the oxidation of iron and aluminum in the soil under conditions of moisture associated with good drainage of rainwater. The moderate sandy-clayey and medium-clayey texture are observed in profiles of different depths, where the podzolization process also occurs. By the Brazilian Soil Classification System - SiBCS (EMBRAPA, 2006), these soils are classified as Clayey Soils. Typically, they present a profile in which the horizon B is always more clayey than the A and E horizons, good drainage, leaching and water percolation conditions in the profile. However, in the cemetery area, it is observed a 
decharacterization of the soil profiles due to the disposal of bones, fragments of coffins, cloths, and ceramic pieces. In addition to formations of dendritic pavement horizons, with a depth of 1.5 meters, formed by small allochthonous pebbles and reworked fragments of the ancient gravels mixed with variable reasons of clay/sand according to the slope of Ground. In this case, the declivity of the cemetery varies between 1.0 and $18 \%$, attesting to the implantation of cemeteries as suggested by Pacheco et al. (1997).

\section{METHODOLOGY}

A total of 18 soil samples were collected in 9 points distributed through the cemetery. The sampling in each of the points was performed in two distinct depth profiles, in $0-0.2 \mathrm{~m}$ (top) and $0.2-0.4 \mathrm{~m}$ (base). The distribution of the sampled points took into account variables such as: terrain slope and visibly critical points (Figure 2). Each of the samples was packaged in polyethylene packaging at an approximate volume of 200 grams. All samples were preserved and left to dry at room temperature for three days in polypropylene molds according to the criteria of Embrapa (2006).

For the analysis of the granulometric parameters, performed in the Universidade Federal do Pampa Laboratory of Mineralogy and Petrology, according to NBR 7181/2016, using a set of three sieves with fractions 80, 100 and 150 mesh for each of the samples. Being the sieves sanitized with a brush and a metal bristles one, in each assay.

The analysis by Energy Dispersive X-ray Fluorescence (EDXRF), model S1 Turbo SD were carried out in the Laboratory of Mineralogy and Petrography-Unipampa, The following operating conditions of the equipment were selected: tube voltage of $15 \mathrm{keV}$ ( $\mathrm{Na}$ to $\mathrm{Sc}$ ) and $50 \mathrm{keV}$ (Ti to $\mathrm{U}$ ) with current in the tube of 184 and $25 \mu \mathrm{A}$ respectively; $10 \mathrm{~mm}$ collimator; $120 \mathrm{~s}$ of real-time integration. The equipment uses an $\mathrm{Ag}$ anode which allows the measurement of 25 elements and a detector of $10 \mathrm{~mm}^{2}$ with thermoelectric cooling and resolution of $\sim 145 \mathrm{eV}$ to MnKa that allows maintaining a speed of 100.000 counts per second (BONA et al. 2007). 
Figure 2 - Location of sampling points

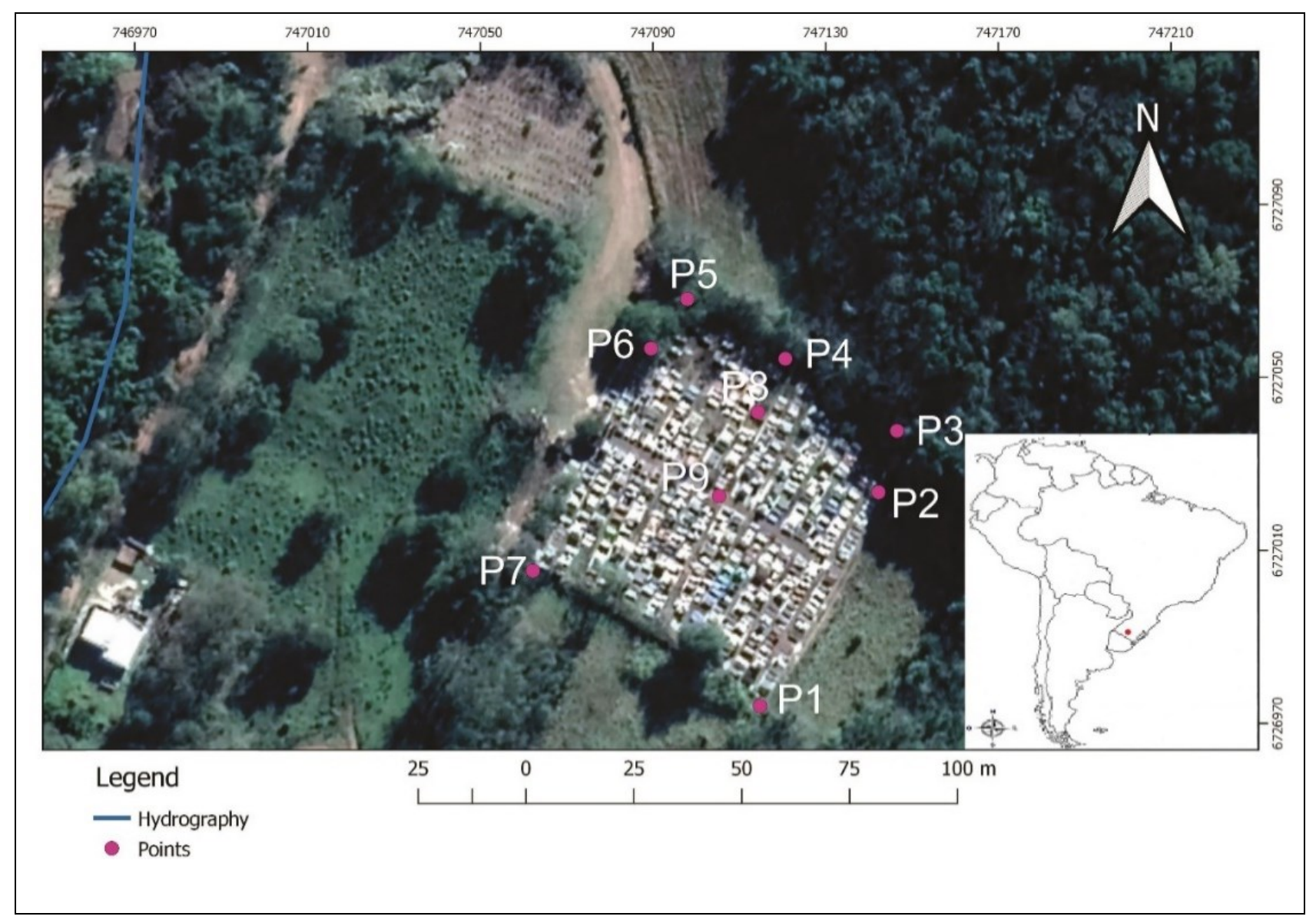

The Principal Component Analysis (PCA) method was used in this study because it is a multivariate statistical technique commonly used to investigate the variability in large geochemical data sets (CHENG et al. 2006; SCHEIB et al. 2011). All correlations and principal components analyses were carried out by using Statistical Package Statsoft version 10. PCA is a variable reduction method that produces a smaller number of artificial variables, known as main components (PCs). Each PC represents a certain amount of data variability, and the first two PCs usually respond by most variations within the entire data group (REIMANN et al. 2008). 


\section{RESULTS AND DISCUSSIONS}

\subsection{Analysis of Granulometric parameters}

The results of the granulometric analysis indicated the physical that differentiate the soils described (Table 1). The granulometric analysis is an important subsidy to avoid degradation and the most appropriate management of the soils (EMBRAPA, 1999; RESENDE et al. 2007; CLEMENTE et al. 2000). In areas used for the cemetery, this type of analysis can optimize the infiltration capacity of the soils and, therefore verify the contaminant flows. The clayey soils are more susceptible to erosion than oxisoils, for example, and they present a clay texture (EMBRAPA, 1999; RESENDE et al. 2007).

Table 1 - Results of the Granulometric Analysis of the Necropolis da Mata, RS

\begin{tabular}{|c|c|c|c|c|c|c|}
\hline \multirow[t]{2}{*}{ Sample } & & \multicolumn{3}{|c|}{ Concentration \% } & \multirow[t]{2}{*}{ Silt/clay } & \multirow[t]{2}{*}{ Class } \\
\hline & & Sand & Silt & Clay & & \\
\hline \multirow[t]{2}{*}{ P_1 } & $\mathrm{a}$ & 48.14 & 4.19 & 47.67 & 0.087 & Clay-sand \\
\hline & $b$ & 53 & 4.19 & 42.81 & 0.097 & Clay-sand \\
\hline \multirow[t]{2}{*}{ P_2 } & $\mathrm{a}$ & 48.7 & 5.15 & 46.14 & 0.111 & Clay-sand \\
\hline & $b$ & 52.64 & 6.37 & 40.99 & 0.155 & Clay-sand \\
\hline \multirow[t]{2}{*}{ P_3 } & $\mathrm{a}$ & 49.37 & 8.04 & 42.59 & 0.188 & Clay-sand \\
\hline & $b$ & 64.5 & 3.84 & 31.62 & 0.121 & Sand-clay \\
\hline \multirow[t]{2}{*}{ P_4 } & $\mathrm{a}$ & 63.84 & 2.96 & 33.21 & 0.089 & Sand-clay \\
\hline & $b$ & 55.65 & 6.63 & 37.72 & 0.175 & Sand-clay \\
\hline \multirow[t]{2}{*}{ P_5 } & $\mathrm{a}$ & 63.23 & 4.34 & 32.44 & 0.133 & Sand-clay \\
\hline & $b$ & 65.1 & 3.35 & 31.48 & 0.106 & Sand-clay \\
\hline \multirow[t]{2}{*}{ P_6 } & $\mathrm{a}$ & 46.37 & 11.45 & 42.17 & 0.271 & Clay-sand \\
\hline & $b$ & 50.16 & 8.77 & 41.07 & 0.213 & Clay-sand \\
\hline \multirow[t]{2}{*}{ P_7 } & $\mathrm{a}$ & 63.57 & 6.41 & 30.02 & 0.213 & Sand-clay \\
\hline & $b$ & 59.58 & 7.23 & 33.19 & 0.217 & Sand-clay \\
\hline \multirow[t]{2}{*}{ P_8 } & $\mathrm{a}$ & 56.17 & 3.82 & 40.01 & 0.095 & Clay-sand \\
\hline & $b$ & 56.07 & 5.45 & 38.48 & 0.141 & Clay-sand \\
\hline \multirow[t]{2}{*}{ P_9 } & $\mathrm{a}$ & 61.61 & 5 & 33.39 & 0.149 & Sand-clay \\
\hline & $\mathrm{b}$ & 52.64 & 10.45 & 36.91 & 0.283 & Sand-clay \\
\hline
\end{tabular}


The granulometric analysis indicated the predominance of clay-sandy and sandy-clayey texture (ABNT, 1995) in the studied profiles, their distribution being random. Many authors have used the silt/clay ratio as an indicator of weathering (EMBRAPA, 1999; RESENDE et al. 2007; CLEMENTE et al. 2000). According to Resende et al. (2007), the soil is considered weathered when this ratio is lower than 0.15 . The silt/clay ratio in the horizon of points 1,4 and 8 tends to a higher degree of weathering than in the other points (Table 1; Figure 3 ). In these points, the ratio average in the superficial layers (0.090) are lower than in deeper layers (0.137).

Figure 3 - The Silt/Clay relation in the Necropolis of Mata, RS, soils

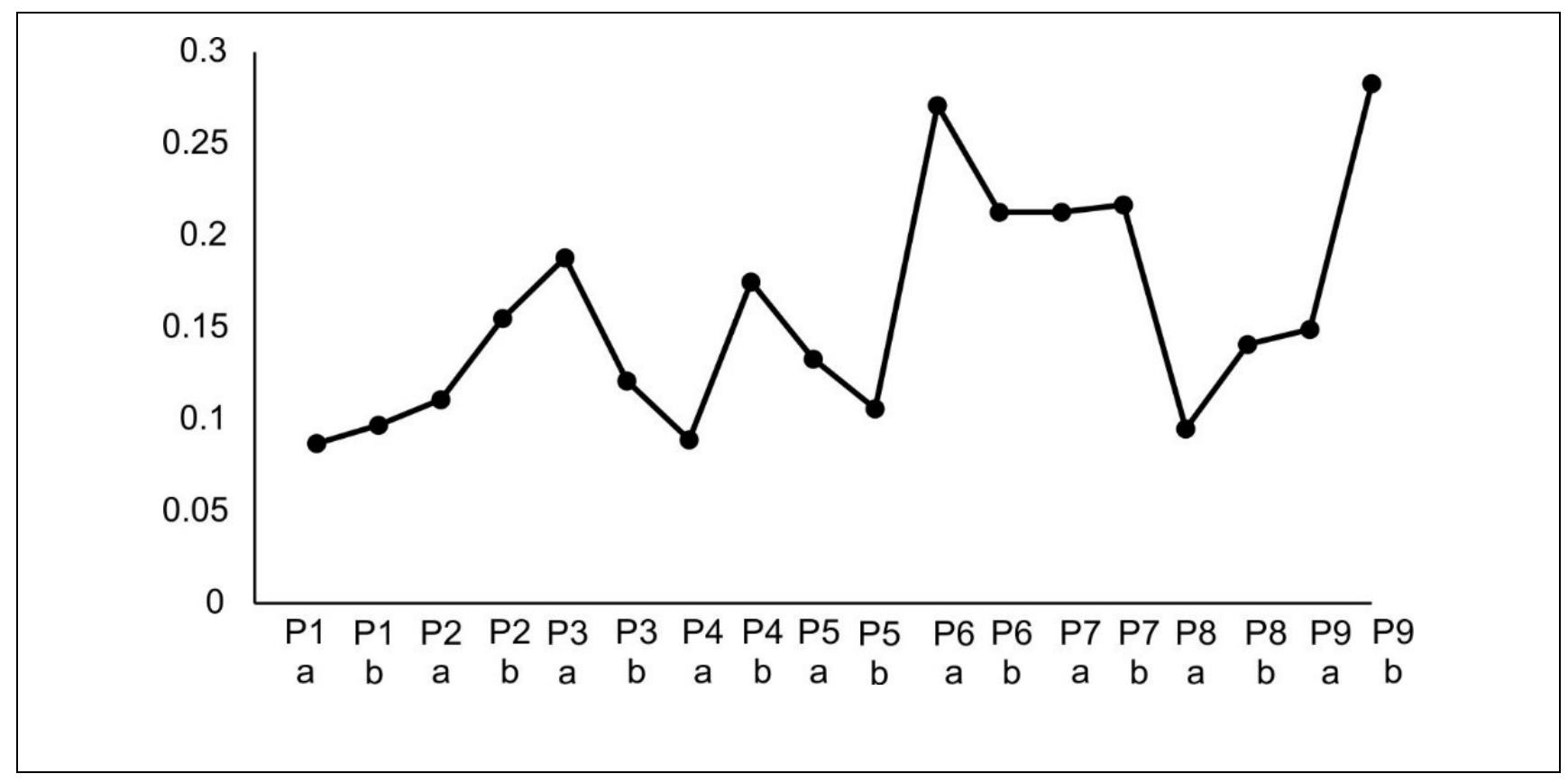

In decreasing order of tendency to weathering we observe the horizons of points $6,7,9,3,5$ and 2 (Figure 4). The deeper layers of points 2, 7 and 9 have a greater amount of silts than clay (Figure 4). Thus, we can infer that the weathering is higher in the higher portion of the terrain (NE and SE). 
Figure 4 - Relative Proportion of Clay, Silt, and Total Sand Soil Contents of Necropolis da Mata, RS

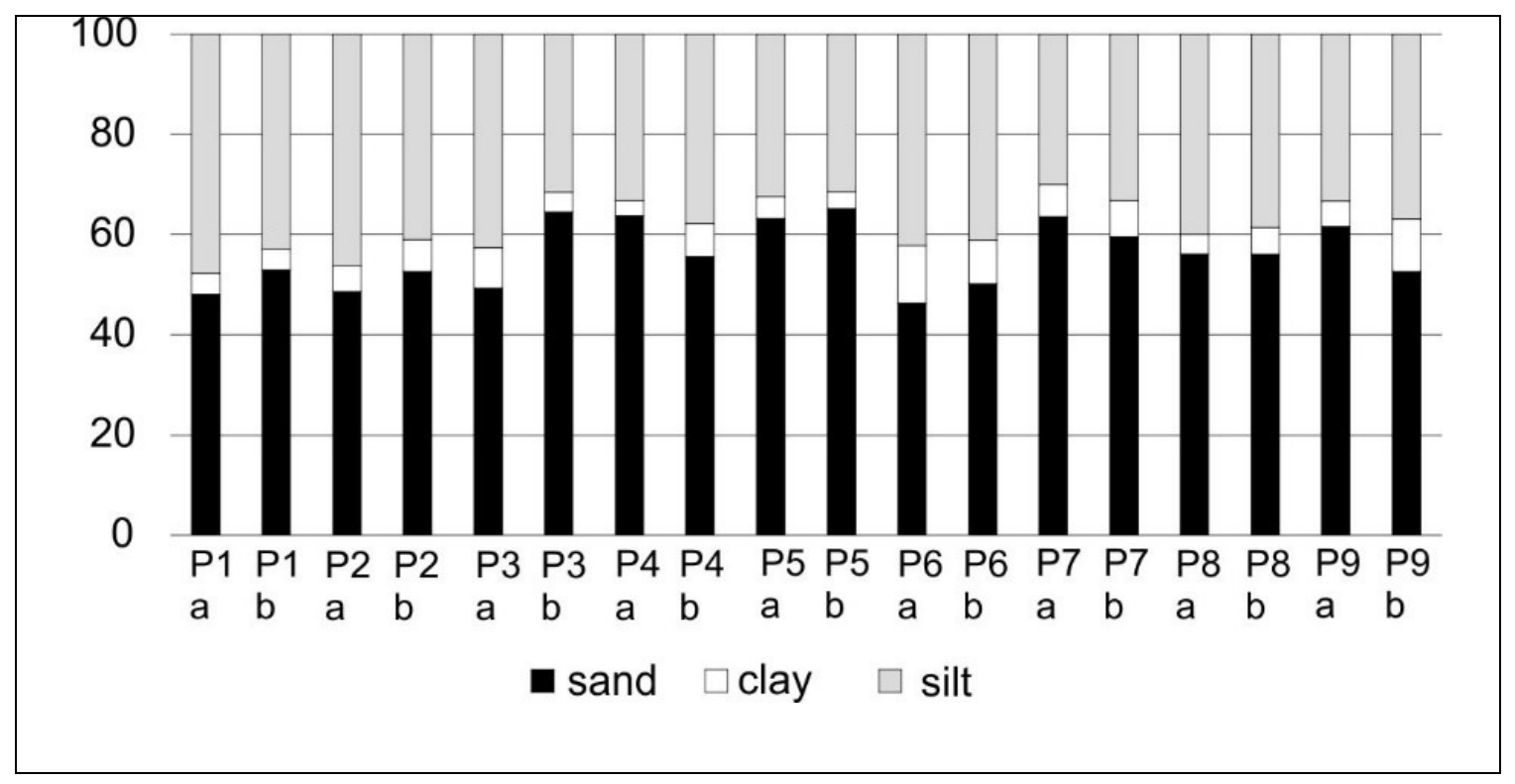

\subsection{Energy Dispersive X-ray Fluorescence (EDXRF)}

The total contents of the analyzed elements (Table 1) were compared with the guiding values of the Resolution $n^{\circ} 420$ of CONAMA (BRASIL, 2009), which is the maximum permissible concentration to avoid harmful alterations to soil quality. The Fe, since it is not referenced in Brazilian legislation, was compared with the guiding values of Macdonald et al. (2000).

In Table 2, it is possible to observe the concentrations of metals and non-metals $\left(\%, \mathrm{ppm}\right.$ and $\left.\mathrm{mg} \mathrm{kg}^{-1}\right)$ in the samples analyzed. All concentrations obtained are below the permissible maximum values for soils, including Fe $\left(<3000 \mathrm{mg} \cdot \mathrm{kg}^{-1}\right)$.

When the results of Table 2 are compared to each other, it can be noted that aluminum values undergo a deep drop in the sampling points P2, P5, and P6. In the collection points P1, P4 and P9 an inverse behavior in the aluminum values was presented, the highest values were observed near the surface. Coincidentally, in points $\mathrm{P} 1$ and $\mathrm{P} 9$, the iron also presents a higher concentration in the surface, as well as $\mathrm{P} 3, \mathrm{P} 5, \mathrm{P} 6$, and $\mathrm{P} 8$. In paragraphs $\mathrm{P} 2$ and $\mathrm{P} 4$, in the same way as aluminum, the iron concentrations decrease as the depth increases. 
The concentration of $\mathrm{Mg}, \mathrm{Si}, \mathrm{K}, \mathrm{Ca}, \mathrm{Ti}, \mathrm{Mn}$ and $\mathrm{Zr}$ varied in proportion with higher values on the surface and in subsurface, independently of the soil type: sandyclay or clayey-sand. Thus, it is not possible to correlate the mobility and constitution of the analyzed material. The $\mathrm{Cu}$ and $\mathrm{Zn}$, when detected, were in the samples in depth $0.30 \mathrm{~m}$. The Rh is only present in the collection points P1 and P7 with higher concentration in depth, sandy-clay and clayey-sand, respectively.

Table 2 - Major elements and traces from the analyzed soils

\begin{tabular}{c|c|c|c|c|c|c|c|c|c|c|c|c|c|c|c|c}
\hline \multicolumn{1}{c|}{ Sample } & \multicolumn{10}{|c|}{ Concentração em \%, base seca } \\
\hline & & Mg & Al & Si & Cl & K & Ca & Ti & Mn & Fe & Cu & Zn & Rh & Cd & Ce & Pd \\
\hline P_1 & a & 5.67 & 1.36 & 7.38 & 0.02 & 1.30 & 0.43 & 1.35 & 0.17 & 12.20 & 10 & 10 & 0.5 & 1.9 & 1.5 & nd \\
\hline & b & 10.6 & 1.71 & 5.81 & 0.06 & 0.92 & 0.23 & 0.78 & 0.18 & 7.66 & 10 & 10 & 0.7 & nd & 1.0 & nd \\
\hline P_2 & a & 8.53 & 2.28 & 7.38 & 0.05 & 1.38 & 0.38 & 1.16 & 0.15 & 12.90 & 10 & 10 & nd & nd & nd & nd \\
\hline & b & 8.48 & 1.41 & 5.33 & 0.03 & 1.05 & 0.29 & 0.91 & 0.20 & 13.40 & 10 & nd & nd & 1.7 & nd & 0.5 \\
\hline P_3 & a & 5.14 & nd & 11.3 & nd & 1.39 & 1.00 & 1.13 & 0.19 & 10.80 & 10 & 10 & nd & 2.4 & 1.0 & 0.7 \\
\hline & b & 5.46 & 1.8 & 12.2 & 0.03 & 1.37 & 0.94 & 1.39 & 0.18 & 6.87 & 10 & 10 & nd & 2.0 & 1.4 & nd \\
\hline P_4 & a & 3.62 & 1.78 & 7.54 & 0.02 & 0.75 & 0.47 & 1.28 & 0.16 & 16.50 & 10 & 10 & nd & 2.6 & nd & 0.7 \\
\hline & b & 7.22 & 1.47 & 4.71 & 0.03 & 0.67 & 0.32 & 1.01 & 0.11 & 17.00 & 10 & 10 & nd & 2.5 & nd & 0.5 \\
\hline P_5 & a & 4.60 & nd & 10.4 & 0.01 & 1.02 & 0.76 & 1.73 & 0.23 & 9.93 & 10 & 10 & nd & 2.5 & 1.0 & 0.8 \\
\hline & b & 7.95 & 1.47 & 9.44 & 0.02 & 0.77 & 0.41 & 1.74 & 0.21 & 8.87 & 10 & 10 & nd & 2.1 & 1.0 & 0.6 \\
\hline P_6 & a & 7.89 & nd & 5.75 & 0.02 & 0.80 & 0.19 & 0.94 & 0.16 & 13.50 & 10 & 10 & nd & 2.2 & nd & nd \\
\hline & b & 4.94 & nd & 12.40 & 0.01 & 0.94 & 0.31 & 1.47 & 0.17 & 9.76 & 10 & 10 & nd & 2.7 & 8.4 & 0.8 \\
\hline P_7 & a & 5.08 & nd & 8.46 & 0.01 & 1.03 & 0.73 & 0.94 & 0.26 & 10.80 & 10 & 10 & nd & 2.4 & 0.6 & 0.7 \\
\hline & b & 6.43 & nd & 8.08 & 0.04 & 1.28 & 0.99 & 0.96 & 0.14 & 8.31 & nd & 10 & 0.5 & 2.7 & nd & 0.5 \\
\hline P_8 & a & 6.09 & 1.80 & 10.5 & 0.02 & 1.41 & 0.41 & 1.86 & 0.30 & 9.24 & 10 & 10 & nd & 2.5 & 1.2 & 0.8 \\
\hline & b & 4.46 & 1.94 & 10.30 & 0.04 & 1.12 & 0.31 & 1.75 & 0.21 & 8.75 & 10 & 10 & nd & 2.3 & nd & nd \\
\hline P_9 & a & 5.19 & nd & 11.9 & 0.02 & 1.57 & 0.45 & 2.17 & 0.31 & 9.32 & 10 & 10 & nd & 2.1 & 2.0 & 0.6 \\
\hline & b & 5.6 & nd & 9.28 & 0.03 & 1.19 & 0.33 & 1.66 & 0.28 & 8.78 & 10 & 10 & nd & 1.8 & 1.3 & 0.6 \\
\hline
\end{tabular}

Note: $\mathrm{nd}=$ Value minor than the detection threshold

The $\mathrm{Ce}, \mathrm{Cd}$ and $\mathrm{Pd}$ were also detected in large part in the analyzed samples. The Ce accompanies the $\mathrm{K}$, having a negative tendency with the Fe. The Ce is a rare earth element (ETR) and presents ionic radius similar to Ca. Thus, it has the capacity to replace it in the crystalline structure of minerals that are raw materials for the manufacture of phosphate fertilizers. Considering that the fertilizers most used in Brazilian agriculture are simple superphosphate and triple superphosphate (VILELA, 2015), it appears that the content of Ce may be related to the contribution of ETR in the soil and, consequently, being accumulated over the years. The Cd may also be

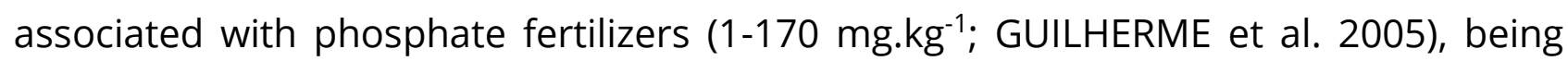


leached by water and deposited in sediments (BELLUTA et al. 2008). An anthropogenic source that improperly deposits equipment such as batteries and batteries, can also be considered responsible for this contaminant (CETESB, 2016).

The Pd together with $\mathrm{Rh}$ are elements of the platinum group, being resistant to weathering. This behavior suggests leaching of soluble components or aggregation of secondary minerals and subsequent concentration in the soil. In addition to this, the local topography is inferred through the hypsometric map (Figure 5). Figure 5 shows the hypsometric map with its respective dimensions with intervals of 10 meters of altitude. The hypsometric map allowed the knowledge of the altimetric variations of the region for a better understanding of the relief behavior and related processes. As well as, it allowed the verification of the limits and the occurrence of the main elevations within the area under study.

Figure 5 - Hypsometric Map obtained from the digital elevation model of the region surrounding the Municipal Cemetery of Mata-RS

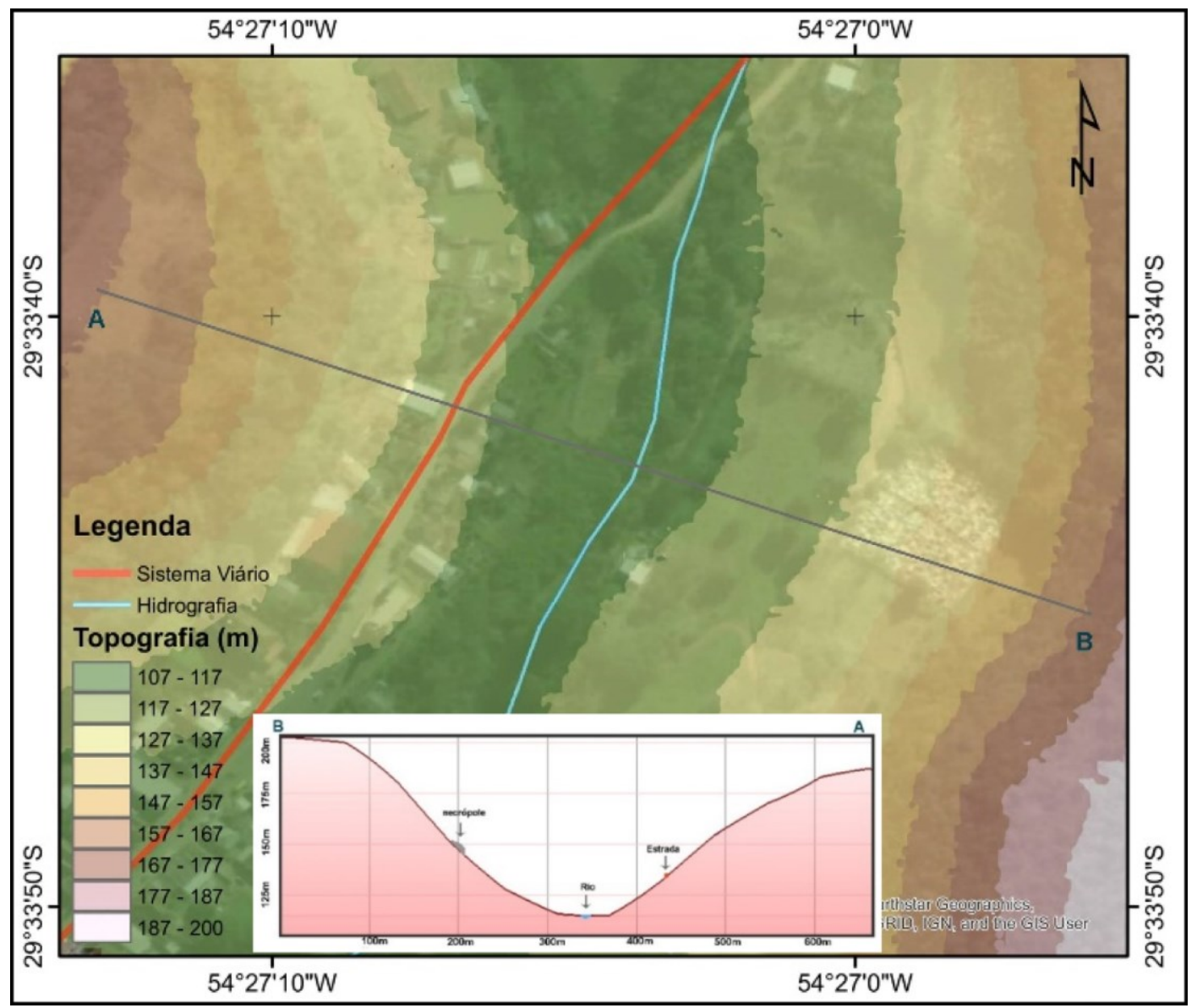




\subsection{Statistical analysis}

Correlation analysis was obtained using Pearson's correlation coefficient (R), which is a bivariate correlation. The variables that present $r>0.7$ are considered strongly correlated, while $r>0.5-0.7$ shows moderate correlation at a significant level ( $P \leq 0.05$ with a confidence level of 95\%; Table 3; MUKAKA, 2012), positive or negative. Sillanpãã (1972) and Alloway et al. (1990), suggest that the total content and its correlations in the source material reflect its content in the sediments.

Table 3 shows the samples with a depth of 0 -meter strong positive correlations between $\mathbf{A l}$ and $\mathrm{Cl} ; \mathbf{S i}$ and $\mathrm{Ti}, \mathrm{Mn}, \mathrm{Ce}, \mathrm{Pd} ; \mathbf{K}$ and $\mathrm{Ce}$; $\mathbf{T i}$ and $\mathrm{Ce}$. Moderate positive correlations are observed for $\mathbf{M g}$ and $\mathrm{Cl}$; $\mathbf{S i}$ and $\mathrm{K}, \mathrm{Ca} ; \mathbf{C a}$ and $\mathrm{Pd}$; $\mathbf{T i}$ and $\mathrm{K} ; \mathbf{M n}$ and $\mathrm{Ce}$, $\mathrm{Pd}$; $\mathbf{C d}$ and $\mathrm{Pd}$. In addition, it demonstrates strong negative correlations between $\mathbf{M g}$ and $\mathrm{Cd}, \mathrm{Pd}$; $\mathbf{S i}$ and Fe; $\mathbf{C l}$ and $\mathrm{Cd} ; \mathbf{M n}$ and Fe; Fe and Ce. Whereas, moderate negative correlations are observed between $\mathbf{M g}$ and $\mathrm{Ca} ; \mathbf{A l}$ and $\mathbf{C d} ; \mathbf{C l}$ and $\mathrm{Ca}, \mathrm{Pd} ; \mathbf{K}$ and $\mathrm{Fe} ; \mathbf{T i}$ and Fe. Rh only presented weak correlations, being positive with $\mathrm{Al}, \mathrm{K}$, and $\mathrm{Ce}$, and the negative ones with $\mathrm{Si}, \mathrm{Ca}, \mathrm{Mn}$ and $\mathrm{Pd}$.

The samples collected at a $0.30 \mathrm{~m}$ depth show strong positive correlations between $\mathrm{Si}$ and $\mathrm{Ti} ; \mathrm{Cl}$ and $\mathrm{Rh}$. Moderate positive correlations are observed between $\mathbf{M g}$ and $\mathrm{Cl}$, Rh; $\mathrm{Si}$ and $\mathrm{Ce} ; \mathbf{K}$ and $\mathrm{Ca} ; \mathbf{T i}$ and $\mathbf{M n} ; \mathbf{C d}$ and $\mathrm{Pd}$. Strong negative correlations occur between $\mathbf{M g}$ and $\mathrm{Si}, \mathrm{Cd} ; \mathbf{A l}$ and $\mathrm{Pd} ; \mathbf{C l}$ and $\mathrm{Cd}, \mathrm{Pd}$. Whereas moderate negative correlations were observed between $\mathbf{M g}$ and $\mathrm{Ti} ; \mathbf{C l}$ and $\mathrm{Ti}, \mathrm{Ce} ; \mathrm{K}$ and $\mathrm{Fe} ; \mathrm{Ti}$ and $\mathrm{Rh} ; \mathrm{Rh}$ and Cd (Table 3).

The main ion exchanges correlate with the correlation coefficients found within the same order. Therefore, it is possible that the simultaneous increase or decrease in cations is the result, mainly, of ion exchange effects in the mineral assemblage of the sediment investigated. 
Table 3 - Pearson correlation for elements investigated in soil

\begin{tabular}{|c|c|c|c|c|c|c|c|c|c|c|c|c|c|}
\hline $\begin{array}{l}\text { Depth0m } \\
\text { Element }\end{array}$ & Mg & Al & Si & $\mathrm{Cl}$ & K & $\mathrm{Ca}$ & $\mathrm{Ti}$ & Mn & $\mathrm{Fe}$ & ${ }^{*} \mathbf{R h}$ & ${ }^{*} \mathrm{Cd}$ & ${ }^{*} \mathrm{Ce}$ & *Pd \\
\hline$M$ & & - & - & 0 & 18 & -0.55 & 30 & 0 & 2 & 2 & 73 & -0.34 & 70 \\
\hline $\mathrm{Al}$ & 25 & 1.00 & -0.33 & 0.72 & 0.11 & -0.44 & 0.01 & -0.31 & 0.41 & 0.21 & 0.51 & -0.29 & 0.27 \\
\hline $\mathrm{Si}$ & 45 & -0.33 & 1.00 & .45 & 0.64 & 0.59 & 0.70 & .73 & 0.76 & -0.28 & 0.32 & .73 & 72 \\
\hline $\mathrm{Cl}$ & 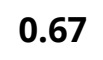 & 70 & 5 & 1.00 & 0.15 & -0.67 & 1 & 0.30 & 0.31 & 0.03 & -0.87 & -0.36 & 0.61 \\
\hline K & 18 & 0.11 & 0.64 & 0.15 & 1.00 & 0.15 & 0.54 & 0.47 & 0.67 & 0.15 & -0.35 & 0.70 & 0.02 \\
\hline $\mathrm{Ca}$ & 55 & -0.44 & 0.59 & -0.67 & 0.15 & 1.00 & -0.06 & 0.16 & -0.36 & -0.16 & 0.33 & 0.23 & .62 \\
\hline $\mathrm{Ti}$ & 29 & 01 & 0 & -0.0 & 0.54 & -0.06 & 1.00 & 1 & -0.57 & -0.04 & 0.18 & 0.74 & .41 \\
\hline $\mathrm{Mn}$ & 30 & -0.31 & 0.73 & -0.30 & 0.47 & 0.16 & 0.71 & 1.00 & 0.80 & -0.27 & 0.39 & .68 & .63 \\
\hline $\mathrm{Fe}$ & 02 & 0.41 & -0.76 & 0.31 & -0.67 & -0.36 & -0.57 & -0.80 & 1.00 & 0.08 & -0.15 & -0.74 & -0.39 \\
\hline${ }^{*} \mathrm{Rh}$ & .02 & 0.21 & -0.28 & 0.03 & 0.15 & -0.16 & -0.04 & -0.27 & 0.08 & 1.00 & -0.08 & .36 & -0.49 \\
\hline${ }^{*} \mathrm{Cd}$ & 73 & 0.51 & 0.32 & -0.87 & 0.35 & 0.33 & 0.18 & 0.39 & -0.15 & -0.08 & 1.00 & 0.28 & .66 \\
\hline${ }^{*} \mathrm{Ce}$ & -0.34 & -0.29 & 0.73 & -0.36 & 0.70 & 0.23 & 0.74 & 0.68 & -0.74 & 0.36 & 0.28 & 1.00 & 0.28 \\
\hline${ }^{*} \mathrm{Pd}$ & .75 & -0.27 & 0.72 & -0.61 & 0.02 & 0.62 & 0.41 & 0.63 & -0.39 & -0.49 & 0.66 & 0.28 & 1.00 \\
\hline $\begin{array}{l}\text { Deptr } \\
\text { m Ele }\end{array}$ & Mg & 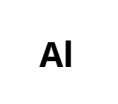 & Si & $\mathrm{Cl}$ & K & $\mathrm{Ca}$ & Ti & Mn & $\mathrm{Fe}$ & 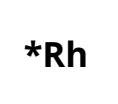 & d & e & d \\
\hline $\mathrm{Mg}$ & 00 & 0.33 & -0.74 & 0.51 & -0.44 & -0.29 & -0.67 & -0.16 & -0.19 & 0.58 & -0.75 & -0.33 & -0.13 \\
\hline $\mathrm{Al}$ & 3 & מר & 0 & 0.3 & 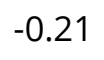 & $-c$ & $-c$ & -0 & -0 & -0.06 & -0.39 & -0.48 & -0.73 \\
\hline $\mathrm{Si}$ & 74 & -0.22 & 1.00 & -0.49 & 0.46 & 0.34 & 0.73 & 0.30 & -0.08 & -0.36 & 0.39 & 0.58 & 0.01 \\
\hline $\mathrm{Cl}$ & 51 & 0.37 & -0.49 & 1.00 & 0.17 & 0.01 & -0.52 & -0.06 & -0.12 & 0.78 & -0.70 & -0.59 & -0.73 \\
\hline K & 44 & -0.21 & 0 & 0. & 1. & 0.67 & 0.10 & 0.31 & -6 & 0 & 0. & -0.10 & -0 . \\
\hline $\mathrm{Ca}$ & 29 & -0.17 & 0.34 & 0.01 & 0.67 & 1.00 & -0.08 & -0.29 & -0.10 & 0.17 & 0.36 & -0.16 & -0.16 \\
\hline Ti & -0.67 & -0.06 & 0.73 & -0.52 & 0.10 & -0.08 & 1.00 & 0.59 & 0.10 & -0.64 & 0.39 & 0.24 & 0.12 \\
\hline $\mathrm{Mn}$ & .16 & -0.12 & 0.3 & 0 & U. & -0.29 & 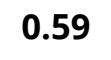 & 1.0 & -0.46 & -0.27 & -0.26 & -0.01 & 0.01 \\
\hline $\mathrm{Fe}$ & .19 & -0.07 & -0.08 & -0.12 & -0.52 & -0.10 & 0.10 & -0.46 & 1.00 & -0.09 & 0.34 & 0.08 & 0.17 \\
\hline${ }^{*} \mathrm{Rh}$ & 0.58 & -0.06 & -0.36 & 0.78 & 0.09 & 0.17 & -0.64 & -0.27 & -0.09 & 1.00 & -0.58 & -0.18 & -0.33 \\
\hline${ }^{*} \mathrm{Cd}$ & -0.75 & -0.39 & 0.39 & -0.70 & 0.08 & 0.36 & 0.39 & -0.26 & 0.34 & -0.58 & 1.00 & 0.23 & 0.51 \\
\hline${ }^{*} \mathrm{Ce}$ & -0.33 & -0.48 & 0.58 & -0.59 & .10 & -0.16 & 0.24 & -0.01 & 0.08 & -0.18 & 0.23 & 1.00 & 0.46 \\
\hline${ }^{*} \mathrm{Pd}$ & 0.13 & -0.73 & 0.01 & -0.73 & -0.34 & -0.16 & 0.12 & 0.01 & 0.17 & -0.33 & 0.51 & 0.46 & 1.00 \\
\hline
\end{tabular}

For a better understanding of the geochemical properties of the investigated soil samples, Principal Component Analysis (PCA) was applied based on the correlation matrix between the chemical components. The first and the second main 
component explain the total variance, due to these present high autovalues (4.24; 2.34 in surface $0 \mathrm{~m}$, and $3.34 ; 1.95$ in the depth of $0.30 \mathrm{~m}$; Table 4). This shows that the first and second major components in the 0-meter depth are responsible for 73.14\% of the total variance, being $47.15 \%$ in PC1 and $25.99 \%$ on PC2. In the depth of $30 \mathrm{~cm}$, the first two PCs accounted for $58.80 \%$ of the variance of the original data, being $37.07 \%$ in $\mathrm{PC} 1$ and $21.72 \%$ in $\mathrm{PC} 2$.

Table 4 - Contribution between each principal component and variables analyzed

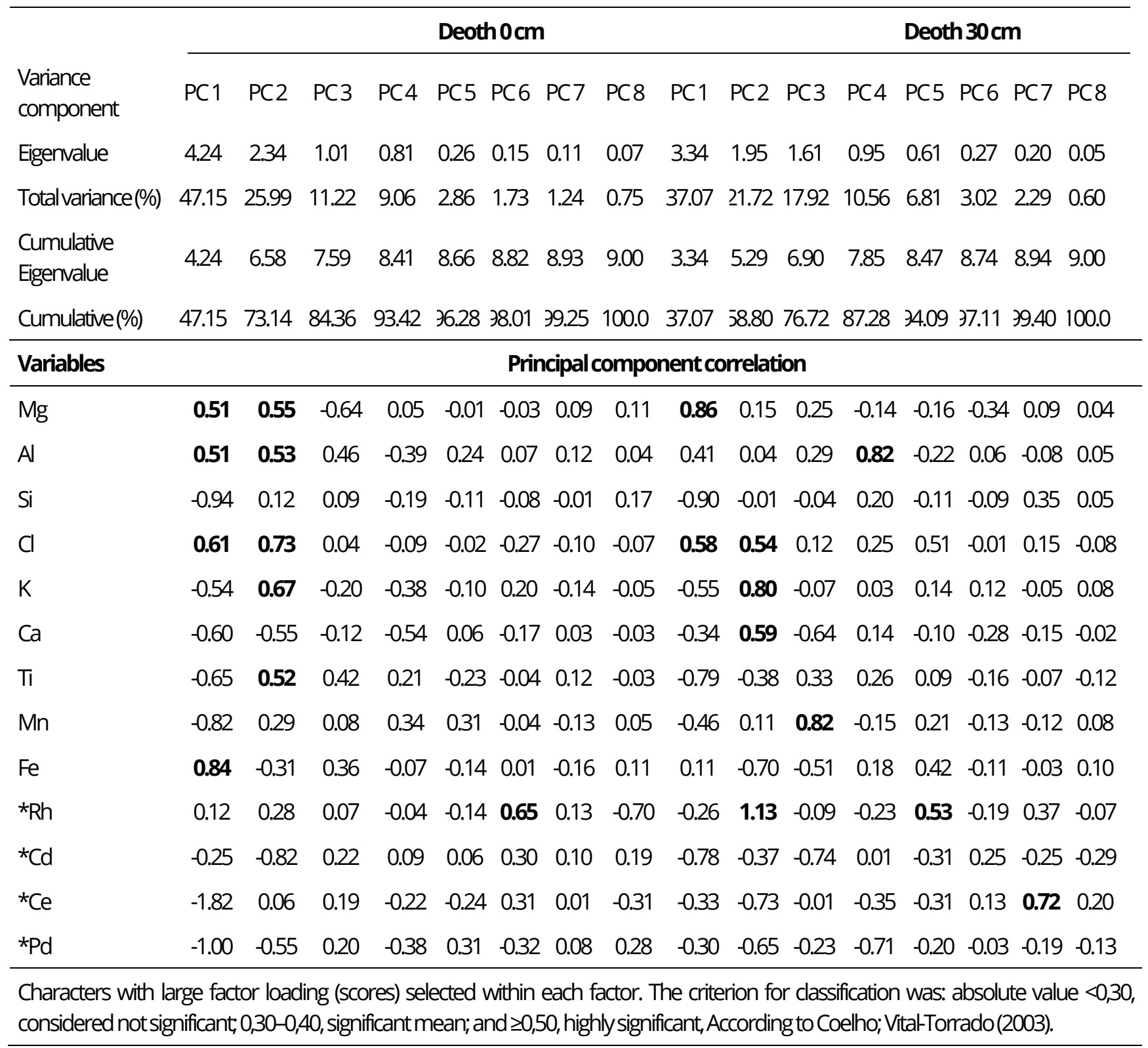


The weights between the variables and the main components allowed to characterize the variables that most discriminated in the formation and differentiation of the investigated soils. Thus, the most strongly correlated variables in the $0 \mathrm{~cm}$ depth were: $\mathrm{Mg}, \mathrm{Al}, \mathrm{Cl}, \mathrm{K}, \mathrm{Fe}$ and $\mathrm{Rh}$ (Table 4; Figure 6A), presenting, in the first and second quadrant, with a small angle in relation to the abscissa axis. In the depth of $0.30 \mathrm{~m}$ (Table 4), a behavior similar to the depth of $0 \mathrm{~cm}$ in relation to its attributes is observed. The most strongly correlated variables were $\mathrm{Mg}, \mathrm{Cl}, \mathrm{Ca}, \mathrm{K}, \mathrm{Rh}$, and $\mathrm{Ce}$ (Table 4; Figure 6B).

Figure 6 - Multivariate analysis of geochemical characteristics of cemetery Mata soil using PCA to extract the principal componentes

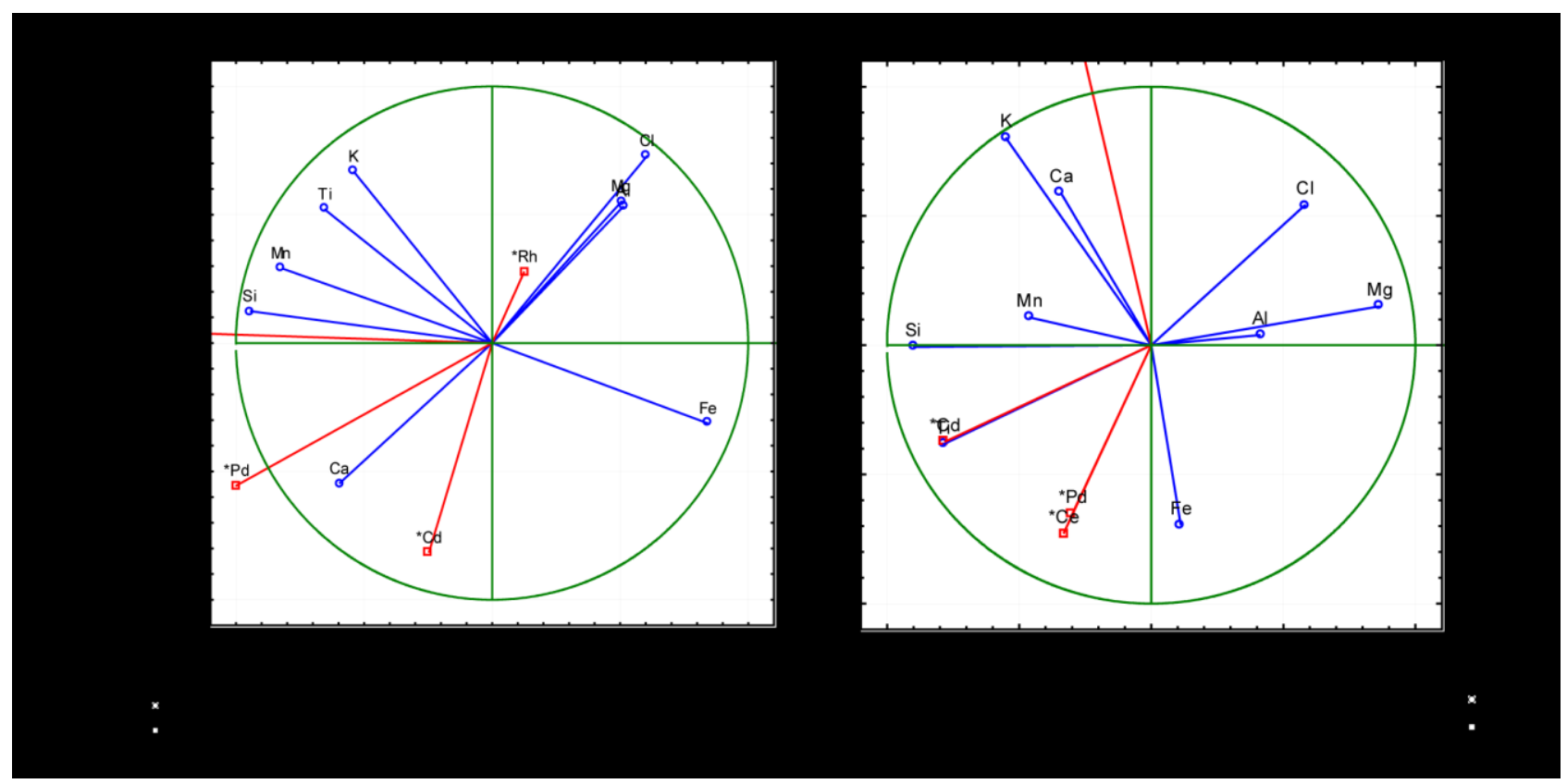

\subsection{Impacts of the study}

In the soils studied, the dominant cation changed was $\mathrm{Mg}$, so it tends to be both surface and depth $(\sim 0.30 \mathrm{~m})$ and $\mathrm{Cl}$ is the dominant anion that completes the charge balance. However, a specific soil characteristic of the Mata cemetery was that Al and Fe were the most important cations in the superficial layers in relation to the calcium of the deepest layers. Under these conditions, the active sulfurization process can occur under acidification conditions related to minerals such as pyrite and hematite, 
being neutralized due to deep carbonates (SILVA, 2000). This result may indicate a difference in geological material with sulfide-bearing materials containing lower pyrite content. At all evaluated depths, the high values of sulfate, aluminum, iron and other metals (TIWARI et al. 2011) characterize a condition of acidification of these soils and consequent increase in the concentration of heavy metals, typical result of the occurrence of a process. of acid mobility in the cemetery.

Thus, soil studies in the Mata region should be continued to answer questions related to human toxicity, eutrophication potential and others.

\section{CONCLUSION}

The water samples collected at Jaguari stream and Lavras do Sul-RS showed water's total hardness ranging from soft to intermediate. The Ph values indicated slightly alkaline to alkaline waters, with electrical ranging from 157.1 to $184.90 \mu \mathrm{S} \mathrm{cm}^{-1}$ and calcium levels fluctuate between 18.27 and $41.31 \mathrm{mg} \mathrm{L}^{-1}$.

The samples were compared using multivariate statistical methods and that exposed strong, positive correlations linking electric conductivity and temperature $(0,60), \mathrm{pH}(0,76)$; calcium and total hardness $(0,76)$; total hardness and $\mathrm{K}(0.67)$ e Rh (0.64); $\mathrm{pH}$ and $\mathrm{Cu}(0.68) ; \mathrm{Rh}$ and $\mathrm{K}(0.70)$. Also shows a strong negative correlation between, electrical conductivity and Si $(-0,65)$; temperature and K $(-0,62)$, Rh $(-0,97)$; Ca and Si $(-0.66)$; total hardness and Si $(-0,65)$; $\mathrm{pH}$ e Si $(-0,66)$; Si and $\mathrm{K}(-0.62)$. The variations at the chemical signatures can be interpreted as derived from interaction with the lithology (for instance, granite, volcanic) and anthropogenic activity.

The distribution of the scores for PC1 and PC2 shows that changes can happen in the geochemistry composition of the waters. To PC1 the highest scores are analogous to the highest charge values $(>0,20)$ of $\mathrm{Cl}$, equal too, to conductivity, temperature and, $\mathrm{pH}$. The lowest scores are similar to the $\mathrm{Cd}$ observed in anthropogenic contribution. High PC2 scores are related to the elements $\mathrm{Fe}, \mathrm{Ag}, \mathrm{Ca}$, $\mathrm{Cu}$ and K. Negative charges and low scores are observed on Mg, Si and at hardness. 


\section{ACKNOWLEDGMENTS}

The authors acknowledge the Research Support Foundation of the State of Rio Grande do Sul - FAPERGS and the Federal University of Pampa - Unipampa for the scholarship programme (187/2018; 69/2019). We are grateful for reviews of anonymous reviewer that led to improvements in the text.

\section{REFERENCES}

ALLOWAY BJ, JACKSON AP, MORGAN H. The accumulation of cadmium by vegetables grown on soils contaminated from a variety of sources. Science of the total Environment. 1990;91: 223-236.

ABNT - Associação Brasileira de Normas Técnicas. Rochas e solos: terminologia, NBR 6502/95. Rio de Janeiro; 1995. 18 p.

BELLUTA I, TOFOLI LA, CORRÊA LC, CARVALHO LR, SILVA AMM. Impactos provocados por metais potencialmente tóxicos dissolvidos em água e em sedimentos no Córrego do Cintra - Botucatu-SP. Salusvita. 2008;27(2):99-118.

BIGARELA JL, SALAMUNI R. Caracteres texturais dos sedimentos da bacia de Curitiba. Boletim da UFPR: Curitiba, 1962; 7:1-164.

BONA IAT, SARKIS JES, SALVADOR VLR, SOARES ALR, KLAMT SC. Análise Arqueométrica de Cerâmica Tupiguarani da Região Central do Estado do Rio Grande do Sul, Brasil, Usando Fluorescência de Raios X por Dispersão de Energia (EDXRF). Química Nova. 2007;30(4):785-790.

BRASIL. FUNDAÇÃO NACIONAL DE SAÚDE. Manual prático de análise de água. 2. ed. rev. Brasília; 2006.

BRASIL. Conselho Nacional do Meio Ambiente. Resolução $n^{\circ}$ 420, de 30 de dezembro de 2009 [Internet]. Available from:

http://www.mma.gov.br/port/conama/res/res09/res42009.pdf. Accessed: 2016-07-24

CETESB. Valores orientadores para solos e águas subterrâneas. 2016 [cited 2017 may 10] Available from: http://www.cetesb.sp.gov.br/wpcontent/uploads/sites/11/2014/12/DD-256-2016-E-Valores-Orientadores-Dioxinas-eFuranos-2016-Intranet.pdf.

CHENG Q, JING L, PANAHI A. Principal component analysis with optimum order sample correlation coefficient for image enhancement. International Journal of Remote Sensing. 2006;27(16):3387-3401. 
CLEMENTE CA, DEMATTÊ JAM, MAFRA AL, BENTIVENHA SRP. Reflectância Espectral e mineralogia de materiais formados sobre diabásio. Scientia Agrícola. 2000;57(1):159168.

COELHO MR, VIDAL-TORRADO P. Caracterização e gênese de perfis plínticos desenvolvidos de arenito do grupo bauru. II- Mineralogia. Revista Brasileira de Ciências do Solo. 2003; 27:495- 507.

EMBRAPA. Centro Nacional de Pesquisa em Solos (CNPS). Sistema Brasileiro de Classificação de Solos. Brasília: EMBRAPA - SPI; 1999; 412.

EMBRAPA. Centro Nacional de Pesquisa de Solos. Sistema brasileiro de classificação de solos. Rio de Janeiro;2006;306.

GOMES CH, ALMEIDA DPM, SPERANDIO DG. Sediment Geochemistry at the Confluence of Baixo Jacuí and Vacacaí-Mirim Hydrographic Basins, Caçapava do SulRS: Implications for Provenance and Chemical Weathering. Anuário do Instituto de Geociências, 2018a;41(3):470-482.

GOMES CH, SPERANDIO DG, DESSART RL, GIUSTI DD. Detection and Evaluation of metals in soil under influence of mining by Dispersive Energy X-ray Fluorescence Spectrometry (EDXRF), Lavras do Sul/RS. Ciência e Natura, 2018b;40-70.

DOI:10.5902/2179460X32289

GONÇALVES GK. SOUSA RO. VAHL LC. BORTOLON L. Solubilização dos fosfatos naturais Pato de Minas e Arad em dois solos alagados. Revista Brasileira de Ciência do Solo. 2008; 32:2157-2164.

GUILHERME LRG, MARQUES JJGSM, PIERANGELI MAP, ZULIANI DQ, CAMPOS ML. Elementos-traço em solos, sedimentos e nas águas. Tópicos em ciência do solo. 2005; 5:345-390.

IBGE-Instituto Brasileiro de Geografia e Estatística. Perfil do seu município: Mata. [Internet] 2018. Available from: http://cidades.ibge.gov.br/xtras/perfil.

JORDÃO CP, ALVES NM, PEREIRA JL, BELLATO CR. Adsorção de íons Cu em Latossolo Vermelho-Amarelo húmico. Química Nova. 2000;23(1):5-11.

LAWRENCE FW, UPCHURCH SB. Identification of recharge areas using geochemical factor analysis. Ground Water. 1982; 20:680-687.

MACDONALD DD, INGERSOLL CG, BERGER T. Development and evaluation of consensus-based sediment quality guidelines for freshwater ecosystems. Arch Environ Contam Toxicol. 2000; 39:20-31.

MALAVOLTA, E. Micronutrientes e metais pesados: mitos, mistificação e fatos. São Paulo: Produquímica;1994;140. 
MATOS BA. Avaliação da ocorrência e do transporte de microrganismo no aqüífero freático do cemitério de Vila Nova Cachoeirinha, município de São Paulo [thesis]. Escola Politécnica da USP: São Paulo;2001.

MUKAKA MM. A guide to appropriate use of correlation coefficient in medical research. Malawi Medical Journal. 2012;24(3):69-71.

PACHECO A, MENDES JMB, HASSUDA S. O problema geo-ambiental da localização de cemitérios em meio urbano. Rev. Sist. Planej. Admin. Metrop. 1997; 17:25-37.

PARAGUASSU A.B. Estruturas sedimentares da Formação Botucatu. Rev. Miner. Metal. 1970;51(301):25-30.

PINTO CS. Curso Básico de Mecânica dos Solos. Oficina de Textos:Porto Alegre; 2000; 247.

REIMANN C, FILZMOSER P, GARRET RG, DUTTER R. Statistical Data Analysis Explained: Applied Environmental Statistics with R. 2008.

RESENDE M, CURI N, REZENDE SB, CORRÊA GF. Pedologia -Base para distinção de ambientes. 5nd ed. Lavras: UFLA;2007.

SCHEIB AJ, LEE JR, BREWARD N, RIDING JB. Reconstructing flow paths of the middle Pleistocene British ice sheet in central-eastern England: The application of regional soil geochemical data. In: Proceedings of the Geologists' Association. 2011; 3:432-444.

SCHERER CMS, FACCINI, UF. LAVINA EL. Arcabouço estratigráfico do Mesozoico da Bacia do Paraná. In: Holz M, ROS LF, editors. Geologia do Rio Grande do Sul. Universidade Federal do Rio Grande do Sul, CIGO;2000;335-354.

SILLANPÄÄ M. Trace elements in soils and agriculture. FAO: Roma (Itália); 1972; 67.

SILVA M. Cemitérios: fonte potencial de contaminação dos aquíferos livres. Revista Sanitária e Ambiental. 2000;71(2):667-681 .

SPONGBERG AL. BECKS PM. Inorganic soil contamination from cemeteries leeched. Water, Air, Soil Polluents. 2000; 117:313-327.

STRECK EV, KAMPF N. DALMOLIN RSD. Solos do Rio Grande do Sul. UFRGS:Porto Alegre; 2002; 222.

TIWARI S, SINGH P, TIWARI R, MEENA KK, YANDIGERI M, SINGH DP, ARORA DK. Salttolerant rhizobacteria-mediated induced tolerance in wheat (Triticum aestivum) and chemical diversity in rhizosphere enhance plant growth. Biol. Fertility Soils. 2011; 47:907-916. 
VILELA LAF. Cério, lantânio, neodímio e ítrio no crescimento de milho na presença e ausência de micorriza em casa de vegetação e da aplicação de mix desses elementos na produção de grãos em campo [thesis]. Universidade Federal de Lavras; 2015.

WASTOWSKI AD, DA ROSA GM, CHERUBIN MR, RIGON JPG. Caracterização dos níveis de elementos químicos em solo, submetido a diferentes sistemas de uso e manejo, utilizando espectrometria de fluorescência de raios-x por energia dispersiva (EDXRF). Química Nova. 2010; 33(7):1449-1452. 